\title{
Analysis of scientific publications in the field of biodiesel in high impact factor journals
}

Camila Almeida Martins

Mestre em Engenharia Mecânica pela Universidade Tecnológica Federal do Paraná (UTFPR). camila_amartins@yahoo.com.br

Pedro Paulo de Andrade Junior

Doutor em Engenharia de Produção pela Universidade Federal de Santa Catarina (UFSC).

Professor do Programa de Pós-graduação em Engenharia e Ciências Mecânicas (Pós-ECM) da Universidade Federal de Santa Catarina - UFSC.

pp.andrade@ufsc.br

Diogo José Horst

Doutor em Engenharia de Produção pela Universidade Tecnológica Federal do Paraná (UTFPR).

Pós-doutorando no Programa de Pós-graduação em Engenharia e Ciências Mecânicas (Pós-ECM) da Universidade Federal de Santa Catarina - UFSC.

diogohorst@gmail.com

Editor Científico: José Edson Lara
Organização Comitê Científico
Double Blind Review pelo SEER/OJS
Recebido em 20.08.2018
Aprovado em 09.04.2019

Este trabalho foi licenciado com uma Licença Creative Commons - Atribuição - Não Comercial 3.0 Brasil 


\section{Abstract}

Background: Biodiesel research has been encouraged by governments, companies and research institutions worldwide.

Objective: This work aimed through a systematic process to select articles published in high impact periodicals, in order to compose a bibliographic portfolio aligned with the biodiesel theme and analyze the profile of these publications.

Method: The work is characterized as descriptive with a qualitative and quantitative approach through bibliometric analysis. The search was conducted in the databases SCOPUS and ScienceDirect through twenty-two keywords.

Results: At first, it was obtained a total of 1030 articles in 193 journals. This number was reduced by selecting the journals with impact factor (JCR) above 2.5 (75\% of the total), thus having a total of 49 journals containing 599 articles. The search resulted in a sample of 30 articles that form the literature portfolio in the Scopus and SienceDirect databases. The principal journals found are: Energy, Energy Policy, Environmental Science and Technology, Fuel, Renewable and Sustainable Energy Reviews.

Key-words: Biodiesel, Scientific Production, Bibliometric Analysis.

\section{Análise de publicações científicas na área de biodiesel em periódicos de alto impacto}

\section{Resumo}

Fundamento: A promoção do desenvolvimento científico e tecnológico sobre biodiesel tem sido incentivada por governos, empresas e instituições de pesquisa de todo o mundo.

Objetivo: Este trabalho objetivou por meio de um processo sistematizado, selecionar artigos publicados em periódicos de alto impacto, para compor um portfólio bibliográfico alinhado com o tema biodiesel e analisar o perfil dessas publicações.

Método: O trabalho caracteriza-se como descritivo com abordagem qualitativa e quantitativa por intermédio da análise bibliométrica. A busca foi realizada nas bases de dados SCOPUS e ScienceDirect por meio de vinte e duas palavras-chave.

Resultados: A princípio obteve-se um total de 1030 artigos em 193 periódicos. Esse número foi reduzido selecionando-se os periódicos com fator de impacto (JCR) acima de 2,5 (75\% do total), obtendo-se assim um total de 49 periódicos contendo 599 artigos. A busca resultou em uma amostra de 30 artigos que formaram o portfólio bibliográfico no banco de dados da Scopus e SienceDirect. Os principais periódicos encontrados são: Energy, Energy Policy, Environmental Science and Technology, Fuel, Renewable and Sustainable Energy Reviews.

Palavras-chave: Biodiesel, Produção científica, Análise bibliométrica. 


\section{Análisis de publicaciones científicas sobre biodiesel en revistas de alto impacto}

\section{Resumen}

Fundamento: La promoción del desarrollo científico y tecnológico del biodiesel ha sido alentada por gobiernos, empresas e instituciones de investigación de todo el mundo.

Objetivo: Este trabajo tuvo como objetivo, a través de un proceso sistemático, seleccionar artículos publicados en revistas de alto impacto, componer un portafolio bibliográfico alineado con el tema del biodiesel y analizar el perfil de estas publicaciones.

Método: El trabajo se caracteriza por ser descriptivo con enfoque cualitativo y cuantitativo a través del análisis bibliométrico. La búsqueda se realizó en las bases de datos SCOPUS y ScienceDirect utilizando veintidós palabras clave.

Resultados: Al principio se obtuvieron un total de 1030 artículos en 193 revistas. Este número se redujo seleccionando revistas con un factor de impacto (JCR) superior a 2.5 (75\% del total), obteniendo así un total de 49 revistas con 599 artículos. La búsqueda resultó en una muestra de 30 artículos que formaron la cartera bibliográfica en la base de datos Scopus y SienceDirect. Las principales revistas encontradas son: Energía, Política energética, Ciencia y tecnología ambiental, Análisis de combustible, energía renovable y sostenible.

Palabras clave: Biodiesel, Producción científica, Análisis bibliométrico.

\section{Introduction}

In recent years, the extent circulation of a publication became an indicative parameter of quality. Given the growing number of articles published worldwide on a particular subject and the inability to keep up with this growth, researchers have begun to develop indexing literature systems that rationalize and facilitate access to this information, and that, combined with informational resources, present themselves as powerful tools for the dissemination of scientific information.

When it comes to survey the state of the art, with a special focus on quantitative focus, bibliometrics attract the interest of researchers, serving as a statistical tool for the management of information and knowledge, as well as a tool for scientific and technological assessment.

Among the main energy sources used worldwide are the petroleum products, however, with high oil prices as a result of the crisis of the 70's and 80's, having environmental, economic 
and social consequences justified by the intensive use of non-renewable energy sources, thereby encouraging the search for biofuels.

In this context, fuels obtained from agricultural products offer an interesting alternative. In addition to the success story of ethanol as an alternative fuel to gasoline, biodiesel stands out.

Biodiesel is technically viable as a fuel, with advantages over petroleum-based fuels, since it generates lower environmental impact and is obtained from renewable sources. Moreover, it presents high biodegradable potential and low toxicity (Meyer, 2011).

The use of biodiesel becomes more and more supported by government policies in both the environmental and social areas. It also has economic advantages, such as the use of its byproducts and the possible reduction of imports of diesel oil. Thus, the main objective of this study was to measure the research output of biodiesel in the SCOPUS and SienceDirect databases. Initially, considerations on the relevance of the biodiesel study are presented. Then a bibliometric review is described as research method, addressing the inclusion, data source and selection of studies criteria. The next item addressed consists of an overview of publications selected and finally the concluding remarks of the study is presented, serving as a foundation for future research on the biodiesel field.

\section{State-of-the-Art}

As a biodegradable fuel, biodiesel can be produced from many different types of vegetables or animal oils, whether in natura or from waste, having physical and chemical characteristics similar to conventional diesel oil. Among the most common renewable sources to obtain it the oilseeds such as soybeans, oil palm, castor and sunflower crops stands out, and also other few diffused crops such as jatropha (Acharya et al., 2019). Depending on the feedstock used, the physical and chemical characteristics of the oil obtained vary smoothly (Neto et al., 2004).

According to the Law No. 11,097, biodiesel can be conceptualized as a biofuel derived from renewable biomass for use in internal combustion engines with compression ignition or, in accordance with regulations, to generate another type of energy that can partially or totally substitute fossil fuels (Brasil, 2005). 
Biodiesel production was stimulated in Brazil by the National Program for Production and Use of Biodiesel. The program has two objectives: ensuring both production and domestic consumption of biodiesel; and promoting diversification of feedstock sources, social inclusion, and regional development by generating employment and income for small rural farmers (Da Silva César, 2019).

Biodiesel can be added to petroleum fuels forming a mixture which can be used in compression ignition diesel engines without any modifications.

The use of vegetable oils as fuel is not new; biodiesel has been studied since the nineteenth century, especially in Europe. According to historical records, the inventor Rudolf Diesel introduced the diesel engine in 1900 in Paris, using a based peanut oil fuel (Knothe, 2010).

The reduction of emission rates of some greenhouse gases is already recognized, resulting in improvements in quality of life and public health. Although its use generates an increase in emission of nitrogen compounds, the biofuels reduces pollutants such as hydrocarbons, carbon monoxide, sulfur oxides, aromatic hydrocarbons and carbon dioxide in comparison to the diesel oil (Abed et al., 2019).

Xue, Grift \& Hansen (2011) performed data collection about the performance and emissions of biodiesel powered engines. The authors analyzed the effects of biodiesel on engines durability and emissions. From results, the use of biodiesel leads to a substantial reduction in emissions of particulates, hydrocarbons and carbon monoxide. In a similar study, based on a literature survey Fazal, Masjuki \& Haseeb (2011) analyzed the advantages and disadvantages of using biodiesel over regular diesel. The authors reached the same conclusion regarding the reduction of emissions. Even more, results of experimental tests made by Buyukkaya (2010) showed a reduction of $9 \%$ and $32 \%$ in $\mathrm{CO}_{2}$ emissions with the use of $\mathrm{B} 5$ (8\% biodiesel) and B100 (100\% biodiesel) respectively.

In addition, other recent studies present technical and environmental analysis on biodiesel powered engines performance and its emissions such as Enweremadu \& Rutto (2010), Dwivedi, Jain \& Sharma (2011), and also Barabás, Todorut \& Bãldean (2010).

Regarding the social point of view, the biodiesel production has promoted the use of unsuitable land for food production, diversifying the Brazilian energy matrix and creating jobs 
and income in rural areas, thus contributing to social inclusion and reducing regional inequalities (Martins \& Andrade Junior, 2016).

Rathmann, Szklo \& Schaeffer (2012) analyzed the National Program for the Production and Use of Biodiesel - PNPB (2004) in the spheres technological, political, environmental and socio-economically. From the socio-economic perspective, the study shows that the generation of jobs in the agricultural sector was much lower than expected. In addition, imports of methanol to produce biodiesel exceed the reduction in diesel imports. However, although the production of biodiesel has not reached the goals of the program, especially in the socioeconomic factor, the energy balance of biodiesel production from soybeans, energy efficiency and the potential for reducing emissions of greenhouse gases supports the implementation and continuous improvement of the program, in order to achieve better results in other indicators.

Despite all the advantages and breakthrough of biodiesel in Brazil, the economic viability for its commercial use requires more detailed analysis. In order that biodiesel could become economically viable, it must be competitive with the diesel oil production cost otherwise its production does not compensate economically. However, this situation began to change due to sudden changes in oil prices.

Araujo, Hamacher \& Scavarda (2010) proposed a method for assessing the biodiesel production cost from wasted frying oils. The study, based on a mathematical model, was applied in Rio de Janeiro. Results showed that the biodiesel production is economically viable, based on the collection of waste frying oils in the city of Rio de Janeiro. Other studies also analyze the economic feasibility of biodiesel and its integration in the market, such as Lopes Neto \& Martins (2011), Szulczyk \& McCarl (2010), Ong et al. (2012), Amigun, Musango \& Brent (2011) and Almeida et al. (2011).

Grasman \& Sadashivam (2012), Kumar, Chaube \& Jain (2012), Caesar \& Battle (2010) and Amigun, Musango \& Brent (2011) discuss the regional policy issues involving the biodiesel implementation and production.

According to data from the Brazilian Union of Biodiesel and Biokerosene - UBRABIO, a success in the biodiesel production is Fertibom, an agribusiness sector company with its own biodiesel production technology from various raw materials having a database with more than 3000 formulations, and an annual production capacity exceeding 120 million liters. 
Another successful example is the JBS biodiesel company, with a production capacity from plant oils and animal fats of 201.600.000 liters per year. It has a fully automated system of production and laboratory testing to ensure the quality of the biofuels.

Some examples of international companies growing in the area are Binatural and Fiagril (Germany), in addition to the producer of raw materials: Evonik Degussa and the equipment supplier Dedini, the last one maintains a laboratory in Belgium for research and testing and a continuous production pilot plant in Italy where process improvements are tested, such as new raw materials additives and reagents.

Biodiesel is an extremely broad term and may be subject of research in several areas. A simple search on the topic results in a huge number of articles addressing this subject in various journals. Moreover, it is observed that the volume of scientific publications increases every year, as the number of periodicals. Thus it becomes necessary to adopt criteria for the selection of articles.

\section{Methodology}

The impact factor of scientific journals is one of the bibliometric tools, based on the relation on the number of times the articles from a journal are cited and the total number of articles published each year. Established as a simple criterion for classifying and assessing the quality of journals, the impact factor has extrapolated its function and now is used as an academic tool to measure the quality of publications. Indeed, governments and funding agencies of several countries use the impact factor as a decision tool for allocating resources to researchers (Garfield, 1999).

The bibliometric literature review, based on selection criteria such as the impact factor and the CAPES concept of classification, is used to point out new research directions or to direct them more accurately. In this case it is important for the research and development (R\&D) of new forms of biodiesel production.

The bibliometric review was chosen because it is a method that allows collecting, selecting and critically analyze studies. The bibliometric review differs from traditional literature review, since the last one allows only an overview of specific issues, being used as an argument for further research. 
In this study, in order to familiarize with the subject, a detailed literature review on the topic was held using the databases SCOPUS and SienceDirect. Information already published on the subject was surveyed, summarized, analyzed and discussed.

A detailed presentation of the methodological procedure adopted is presented below:

First, the keywords and search-period was defined, with a total of twenty-two keywords were established. The search was performed with such keywords combined with the keyword "biodiesel" in the title field. At this stage, were found 637 articles published in ScienceDirect and 787 in SCOPUS. Discounting the duplicate articles a total of 1030 articles in both databases was obtained.

The next step comprises the journals analysis, aiming to reduce the number of items to be used for the development of the bibliometric review, in order to analyze their impact factor or Journal Citation Reports (JCR). From the total 193 journals with impact factor ranging from 14,448 to 0,053 , articles from journals with an impact factor above 2.5 ( $75 \%$ of the total) were selected, accounting a total of 49 journals, containing 599 articles.

Due the huge number of articles found, it was decided to apply two selection criteria. The first was the CAPES classification within the area of Production Engineering (Engineering III); the second selection consisted in analyzing the scope of journals, searching only those within the area of research, in this case Production Engineering. Thus, a total of 463 articles and 13 journals were obtained. From the analysis of the summaries, the number of items was reduced to 30 in 9 journals, and these were used as research bases: Applied Energy, Biomass and Bioenergy, Bioresource Technology, Energy, Energy Policy, Environmental Science and Technology, Fuel, Renewable and Sustainable Energy Reviews, Renewable Energy.

\section{Results and discussion}

As previously explained, 30 articles were selected from 9 journals, the Table 1 shows the keywords used in the search: 


\section{Table 1}

Selected keywords

\begin{tabular}{|c|c|c|}
\hline KW 1 & Social & \multirow{4}{*}{ Viability } \\
\hline KW 2 & Economic & \\
\hline KW 3 & Technical & \\
\hline KW 4 & Environmental & \\
\hline KW 5 & Social & \multirow{3}{*}{ Impacts } \\
\hline KW 6 & Environmental & \\
\hline KW 7 & Regional & \\
\hline KW 8 & Potential & \multirow{2}{*}{ Market } \\
\hline KW 9 & Global & \\
\hline KW 10 & \multicolumn{2}{|c|}{ Tax breaks } \\
\hline KW 11 & \multicolumn{2}{|c|}{ Government incentives } \\
\hline KW 12 & \multicolumn{2}{|c|}{ Production } \\
\hline KW 13 & \multicolumn{2}{|c|}{ By-products } \\
\hline KW 14 & \multicolumn{2}{|c|}{ Raw material } \\
\hline KW 15 & \multicolumn{2}{|c|}{ National policies } \\
\hline KW 16 & \multicolumn{2}{|c|}{ Technological innovation } \\
\hline KW 17 & \multicolumn{2}{|c|}{ Properties } \\
\hline KW 18 & \multicolumn{2}{|c|}{ Performance } \\
\hline KW 19 & \multicolumn{2}{|c|}{ Feasibility } \\
\hline KW 20 & \multicolumn{2}{|c|}{ Market } \\
\hline KW 21 & \multicolumn{2}{|c|}{ Policy } \\
\hline KW 22 & \multicolumn{2}{|c|}{ Incentives } \\
\hline
\end{tabular}

Table 2 shows the journals obtained after the selection criteria and their respective impact factors and CAPES qualification. As can be seen, it is possible to analyze the number of articles per journal and also per keyword. 


\section{Table 2}

Selected journals and number of articles found:

\begin{tabular}{|c|c|c|c|c|c|c|c|c|c|c|c|c|c|}
\hline Journal & $\begin{array}{l}\text { QUALIS } \\
\text { CAPES } \\
\text { Engineeri } \\
\text { ng III }\end{array}$ & $\begin{array}{l}\text { Impact } \\
\text { factor } \\
\text { (JCR) }\end{array}$ & $\begin{array}{c}\mathrm{KW} \\
6\end{array}$ & $\begin{array}{c}\mathrm{KW} \\
12\end{array}$ & $\begin{array}{c}\mathrm{KW} \\
13\end{array}$ & $\begin{array}{c}\mathrm{KW} \\
14\end{array}$ & $\begin{array}{c}\mathrm{KW} \\
17\end{array}$ & $\begin{array}{c}\mathrm{KW} \\
18\end{array}$ & $\begin{array}{c}\text { KW } \\
19\end{array}$ & $\begin{array}{c}\mathrm{KW} \\
20\end{array}$ & $\begin{array}{c}\text { KW } \\
21\end{array}$ & $\begin{array}{c}\mathrm{KW} \\
22\end{array}$ & Total \\
\hline $\begin{array}{c}\text { Renewable } \\
\text { Energy }\end{array}$ & $\mathrm{A} 2$ & 2,580 & - & 18 & 1 & - & 2 & 2 & 1 & - & - & - & 24 \\
\hline Energy Policy & A1 & 2,629 & 1 & 3 & - & 1 & - & 1 & - & - & 1 & - & 7 \\
\hline $\begin{array}{c}\text { Process } \\
\text { Biochemistry }\end{array}$ & A1 & 2,648 & - & 11 & 1 & - & - & 1 & - & - & - & - & 13 \\
\hline $\begin{array}{l}\text { Fuel Processing } \\
\text { Technology }\end{array}$ & A1 & 2,781 & - & - & - & 1 & 1 & 4 & - & - & - & - & 6 \\
\hline $\begin{array}{l}\text { Chemical } \\
\text { Engineering } \\
\text { Journal } \\
\end{array}$ & A1 & 3,074 & - & 15 & 1 & - & - & 1 & - & - & - & - & 17 \\
\hline Energy & A1 & 3,597 & - & 15 & - & - & 3 & 6 & 1 & - & - & - & 25 \\
\hline Fuel & A1 & 3,604 & - & 91 & 1 & - & 14 & 7 & - & - & - & - & 113 \\
\hline $\begin{array}{l}\text { Biomass \& } \\
\text { Bioenergy }\end{array}$ & A1 & 3,840 & 1 & 35 & & - & 4 & 4 & - & 1 & 1 & - & 46 \\
\hline Applied Energy & A1 & 3,915 & - & 25 & - & 1 & - & 8 & - & - & - & 1 & 35 \\
\hline $\begin{array}{c}\text { International } \\
\text { Journal of } \\
\text { Hydrogen } \\
\text { Energy } \\
\end{array}$ & A1 & 4,057 & - & 4 & - & - & - & 1 & - & - & - & - & 5 \\
\hline $\begin{array}{l}\text { Bioresource } \\
\text { Technology }\end{array}$ & A1 & 4,365 & - & 115 & 1 & 1 & 11 & 3 & 2 & - & - & - & 133 \\
\hline $\begin{array}{c}\text { Renewable and } \\
\text { Sustainable } \\
\text { Energy } \\
\text { Reviews }\end{array}$ & A1 & 4,595 & - & 22 & - & - & 1 & 5 & 2 & 2 & - & - & 32 \\
\hline $\begin{array}{c}\text { Environmental } \\
\text { Science and } \\
\text { Technology }\end{array}$ & A1 & 4,827 & 1 & 5 & - & - & - & 1 & - & - & - & - & 7 \\
\hline TOTAL & & & 3 & 359 & 5 & 4 & 36 & 44 & 6 & 3 & 2 & 1 & 463 \\
\hline
\end{tabular}

The Figure 1 and Figure 2 show a different perspective of the data present in Table 2: 


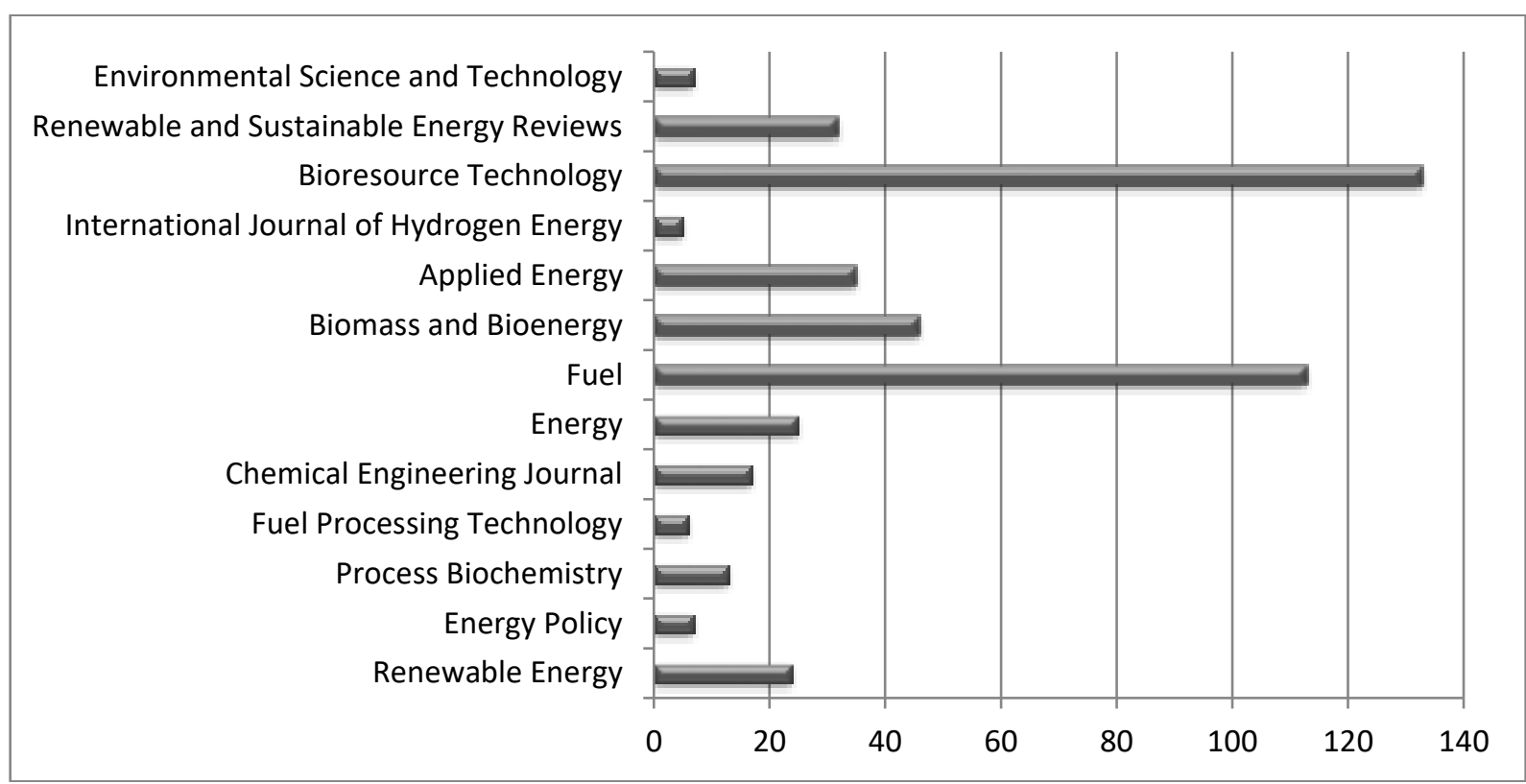

Figure 1 - Articles published per journal

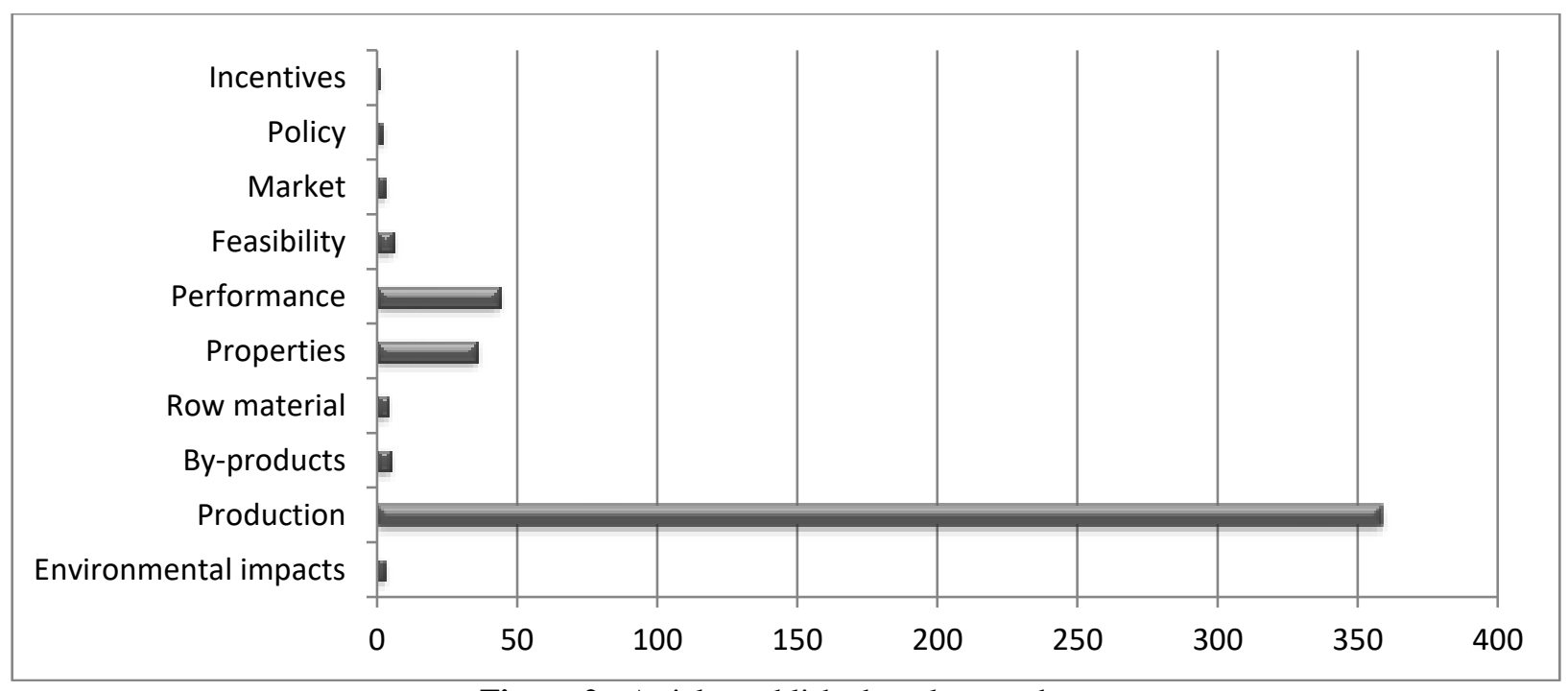

Figure 2 - Articles published per keyword

Accordingly, the keyword present in the highest number of articles was "Production" (KW 12) with 359 articles, followed by "performance" (KW 18), with 44 and "Properties" (KW 17) with 36. The journal with the highest number of articles was Bioresource Technology with 133, followed by Fuel with 113.

The Table 3 presents the 30 articles selected from the analysis of the abstracts: 


\section{Table 3}

Selected papers after abstracts review

\begin{tabular}{|c|c|c|}
\hline Journal & Author & Article Title \\
\hline $\begin{array}{l}\text { Applied } \\
\text { Energy }\end{array}$ & Régis Rathmann & $\begin{array}{l}\text { Targets and results of the Brazilian Biodiesel Incentive } \\
\text { Program - Has it reached the Promised Land? }\end{array}$ \\
\hline \multirow[b]{2}{*}{$\begin{array}{l}\text { Biomass \& } \\
\text { Bioenergy }\end{array}$} & Scott E. Grasman & $\begin{array}{l}\text { Implementation policy considerations for achieving year- } \\
\text { round operability of biodiesel programs }\end{array}$ \\
\hline & Zanxin Wang & $\begin{array}{l}\text { Lifecycle assessment of the economic, environmental and } \\
\text { energy performance of Jatrophacurcas L. biodiesel in } \\
\text { China }\end{array}$ \\
\hline \multirow{2}{*}{$\begin{array}{l}\text { Bioresource } \\
\text { Technology }\end{array}$} & Sunil Kumar & $\begin{array}{l}\text { A comprehensive life cycle assessment (LCA) of Jatropha } \\
\text { biodiesel production in India }\end{array}$ \\
\hline & $\begin{array}{c}\text { Victor K. } \\
\text { Wermelinger } \\
\text { Sancho Araujo }\end{array}$ & $\begin{array}{l}\text { Economic assessment of biodiesel production from waste } \\
\text { frying oils }\end{array}$ \\
\hline \multirow{4}{*}{ Energy } & B. Amigun & $\begin{array}{l}\text { Community perspectives on the introduction of biodiesel } \\
\text { production in the Eastern Cape Province of South Africa }\end{array}$ \\
\hline & $\begin{array}{l}\text { Daniela de C. } \\
\text { Lopes }\end{array}$ & Economic simulation of biodiesel production: SIMB-E tool \\
\hline & L. Talens Peiró & $\begin{array}{l}\text { Extended exergy accounting applied to biodiesel } \\
\text { production }\end{array}$ \\
\hline & L. Talens Peiró & $\begin{array}{l}\text { Life cycle assessment (LCA) and exergetic life cycle } \\
\text { assessment (ELCA) of the production of biodiesel from used } \\
\text { cooking oil (UCO) }\end{array}$ \\
\hline \multirow{6}{*}{ Energy Policy } & $\begin{array}{l}\text { Aldara da Silva } \\
\text { César }\end{array}$ & $\begin{array}{l}\text { Biodiesel production from castor oil in Brazil: A difficult } \\
\text { reality }\end{array}$ \\
\hline & Julian A. Quintero & $\begin{array}{l}\text { Social and techno-economical analysis of biodiesel } \\
\text { production in Peru }\end{array}$ \\
\hline & Liao Yanfen & $\begin{array}{l}\text { Energy analysis and environmental impacts of microalgal } \\
\text { biodiesel in China }\end{array}$ \\
\hline & Seksan Papong & $\begin{array}{l}\text { Life cycle energy efficiency and potentials of biodiesel } \\
\text { production from palm oil in Thailand }\end{array}$ \\
\hline & Scott O. Shrake & $\begin{array}{l}\text { A comparative analysis of performance and cost metrics } \\
\text { associated with a diesel to biodiesel fleet transition }\end{array}$ \\
\hline & Sunil Kumar & $\begin{array}{l}\text { Critical review of jatropha biodiesel promotion policies in } \\
\text { India }\end{array}$ \\
\hline \multirow{3}{*}{$\begin{array}{l}\text { Environmental } \\
\text { Science and } \\
\text { Technology }\end{array}$} & Achten, W.M.J. & $\begin{array}{l}\text { Life cycle assessment of a palm oil system with } \\
\text { simultaneous production of biodiesel and cooking oil in } \\
\text { Cameroon }\end{array}$ \\
\hline & Almeida, J. & $\begin{array}{l}\text { Benchmarking the environmental performance of the } \\
\text { jatropha biodiesel system through a generic life cycle } \\
\text { assessment }\end{array}$ \\
\hline & Biswas, W.K. & $\begin{array}{l}\text { Biodiesel production in a semiarid environment: A life cycle } \\
\text { assessment approach }\end{array}$ \\
\hline \multirow{3}{*}{ Fuel } & Ekrem Buyukkaya & $\begin{array}{l}\text { Effects of biodiesel on a DI diesel engine performance, } \\
\text { emission and combustion characteristics }\end{array}$ \\
\hline & H.C. Ong & $\begin{array}{l}\text { Life cycle cost and sensitivity analysis of palm biodiesel } \\
\text { production }\end{array}$ \\
\hline & István Barabás & $\begin{array}{l}\text { Performance and emission characteristics of an CI engine } \\
\text { fueled with diesel-biodiesel-bioethanol blends }\end{array}$ \\
\hline \multirow{2}{*}{$\begin{array}{l}\text { Renewable and } \\
\text { Sustainable } \\
\text { Energy } \\
\text { Reviews }\end{array}$} & C.C. Enweremadu & $\begin{array}{l}\text { Combustion, emission and engine performance } \\
\text { characteristics of used cooking oil biodiesel-A review }\end{array}$ \\
\hline & Gaurav Dwivedi & $\begin{array}{l}\text { Impact analysis of biodiesel on engine performance }-\mathrm{A} \\
\text { review }\end{array}$ \\
\hline
\end{tabular}




\begin{tabular}{c|c|l}
\cline { 2 - 3 } & Ingrid Lozada & $\begin{array}{l}\text { Environmental and economic feasibility of palm oil } \\
\text { biodiesel in the Mexican transportation sector }\end{array}$ \\
\cline { 2 - 3 } & Jinlin Xue & Effect of biodiesel on engine performances and emissions \\
\cline { 2 - 3 } $\begin{array}{c}\text { Kenneth } \\
\text { R. Szulczyk }\end{array}$ & Market penetration of biodiesel \\
\cline { 2 - 3 } & M.A. Fazal & $\begin{array}{l}\text { Biodiesel feasibility study: An evaluation of material } \\
\text { compatibility; performance; emission and engine durability }\end{array}$ \\
\cline { 2 - 3 } & Ardebili & Biodiesel production potential from edible oil seeds in Iran \\
\hline \multirow{3}{*}{$\begin{array}{c}\text { Renewable } \\
\text { Energy }\end{array}$} & Johan Pienaar & $\begin{array}{l}\text { A model for evaluating the economic feasibility of small- } \\
\text { scale biodiesel production systems for on-farm fuel usage }\end{array}$ \\
\cline { 2 - 3 } & Sulaiman Al-Zuhair & $\begin{array}{l}\text { Enzymatic production of biodiesel from used/waste } \\
\text { vegetable oils: Design of a pilot plant }\end{array}$ \\
\hline
\end{tabular}

Starting from a total of 1,030 articles on the topic published in the databases ScienceDirect and SCOPUS, the selection process resulted in 30 articles distributed among 9 renowned journals (Table 3). These journals present high impact factor and CAPES concept "A" within the area of Production Engineering (classification Engineering III).

Selected articles cover various aspects of biodiesel production. For example, articles published in the journal Environmental Science and Technology deeply address environmental issues. Articles published in journal Fuel besides the environmental factors also take into account the analysis of engine performance and also economic factors.

Wang, Lu \& Calderon (2011), Kumar Chaube \& Jain (2012), Peiróet al. (2010), Papong et al. (2010) and also Yanfen, Zehao \& Xiaoqian (2012) present an energy analysis in addition to the economic and environmental analyzes.

Shrake (2010) \& Enweremadu Rutto (2010), Dwivedi, Jain \& Sharma (2011), Xue, Grift \& Hansen (2011), Fazal, \& Masjuki Haseeb (2011) published studies with performance analysis of biodiesel-fueled engines.

Further analysis in the area of production is done by Grasman \& Sadashivam (2012), Araujo, Hamacher \& Scavarda (2010), kumaret al. (2012), Szulczyk \& McCarl (2010) and also Ardebili et al. (2011).

As a result, we can see a rapid growing of scientific publications in the field of biodiesel in high impact factor journals addressing issues such as: Biodiesel Incentive Program, implementation of policy considerations to achieving year-round operability of biodiesel programs, lifecycle assessment of the economic and environmental issues, effect of biodiesel on engine performance and emissions, costing of raw material, economic assessment of biodiesel production from waste frying oils, among others. 


\section{Final considerations}

The use of biodiesel as fuel becomes a supporting tool for government policies comprising the environmental and social areas. It has introduced as well, economic advantages, such as the use of its byproducts and the possible reduction of diesel oil imports.

Biodiesel is an extreme broad term and research subject in several areas. A simple search on the topic results in a huge number of articles addressing the subject in various journals. Moreover, the increasing number of articles published worldwide on this particular subject makes it impossible to monitor this growth. Thus it becomes necessary to adopt criteria for indexing, sorting and selecting the information obtained.

The bibliometric literature review was based on the impact factor and the CAPES concept of classification, used to point out new research directions or direct them more accurately. The bibliometric analysis on the topic Biodiesel obtained a total of 463 articles and 13 journals. Being $28.7 \%$ of the articles published in the journal Bioresource Technology and $24.4 \%$ in the journal Fuel, followed by Biomass and Bioenergy with 9.9\%. Emphasizing that in $77.5 \%$ of the articles titles contains the keyword "Production" (KW 12), 9.5\% "Performance" (KW 18) and 7.8\% "Properties" (KW 17).

From the abstract analysis, the number of items was reduced to 30 in 9 journals: Applied Energy, Biomass \& Bioenergy, Bioresource Technology, Energy, Energy Policy, Environmental Science and Technology, Fuel, Renewable and Sustainable Energy Reviews, and Renewable Energy.

Remembering that articles selected cover various aspects of biodiesel production, such as environmental issues, in the case of articles published in the journal Environmental Science and Technology, for example, or technical and economic factors, such as articles published in the journal Fuel.

The bibliometric literature review on biodiesel shows an annual increase in the volume of international publications on the topic. Mainly due its importance as an alternative to petroleum, providing economic benefits such as the use of its byproducts and possible reduction of diesel imports. However, despite the quantitative and qualitative growth of publications, scientific production in the area still features gaps and research opportunities. 
In terms of future referrals referring to the field of scientific research it is suggested to broaden the search to other periodicals databases. In terms of $R \& D$ it is important to develop new forms of biodiesel production. In terms of the market it is necessary to identify new technologies, raw materials, production of biodiesel in pilot scale, so that biodiesel becomes an interesting alternative, by reducing diesel imports and resulting products, thus enabling the development in other industrial chains.

\section{Aknowledgements}

This study was financially supported by the Coordenação de Aperfeiçoamento de Pessoal de Nível Superior - CAPES, Brazil, financial code [001].

\section{References}

Abed, K. A.; Gad, M. S.; El Morsi, A. K.; Sayed, M. M.; Elyazeed, S. A. (2019). Effect of biodiesel fuels on diesel engine emissions. Egyptian Journal of Petroleum, IN PRESS.

Acharia, N.; Nanda, P.; Panda, S.; Acharya, S. (2019). Scientific production in the area features gaps and research opportunities. Journal of King Saud University - Engineering Sciences, 31(2), 184-190.

Achten, W. M. J. et al. (2010) .Life cycle assessment of a palm oil system with simultaneous production of biodiesel and cooking oil in Cameroon. Environmental Science and Technology, $44,4809-4815$.

Almeida, J. et al. (2011). Benchmarking the environmental performance of the jatropha biodiesel system through a generic life cycle assessment. Environmental Science and Technology, 45, 5447-5453.

Al-Zuhair, S. et al. (2011). Enzymatic production of biodiesel from used/waste vegetable oils: Design of a pilot plant. Renewable Energy, 36, 2605-2614.

Amigun, B.; Musango, J. K.; Brent, A. C. (2011). Community perspectives on the introduction of biodiesel production in the Eastern Cape Province of South Africa. Energy, 36, 2502-2508.

Araujo, V. K. W. S.; Hamacher, S.; Scavarda, L. F. (2010). Economic assessment of biodiesel production from waste frying oils. Bioresource Technology, 101, 4415-4422. 
Ardebili, M. et al. (2011). Biodiesel production potential from edible oil seeds in Iran. Renewable and Sustainable Energy Reviews, 15, 3041-3044.

Barabás, I.; Todorut, A.; Baldean, D. (2010). Performance and emission characteristics of an CI engine fueled with diesel-biodiesel-bioethanol blends. Fuel, 89, 3827-3832.

Biswas, W. K.; Barton, L.; Carter, D. (2011). Biodiesel production in a semiarid environment: A life cycle assessment approach. Environmental Science and Technology, 45, 3069-3074.

Brasil (2005). Lei $N^{\circ} 11.097$ de 13 de Janeiro de 2005. Dispõe sobre a introdução do biodiesel na matriz energética brasileira; altera as Leis nos 9.478, de 6 de agosto de 1997, 9.847, de 26 de outubro de 1999 e 10.636, de 30 de dezembro de 2002; e dá outras providências. Presidência da República, Brasília-DF. 2005b. Recuperado em 28 Março, 2019 de http://www.planalto.gov.br/ccivil_03/_Ato2004-2006/2005/Lei/L11097.html

Buyukkaya, E. (2010). Effects of biodiesel on a DI diesel engine performance, emission and combustion characteristics. Fuel, 89, 3099-3105.

César, A. S.; Batalha, M. O. (2010). Biodiesel production from castor oil in Brazil: A difficult reality. Energy Policy, 38, 4031-4039.

Da Silva César, A.; Conejero, M.A.; Barros Ribeiro, E.C.; Batalha, M.O. (2019). Competitiveness analysis of "social soybeans" in biodiesel production in Brazil. Renewable Energy, 133, 1147 1157.

Dwivedi, G.; Jain, S.; Sharma, M. P. (2011). Impact analysis of biodiesel on engine performance - A review. Renewable and Sustainable Energy Reviews, 15, 4699-4641.

Enweremadu, C. C.; Rutto, H. L. (2010). Combustion, emission and engine performance characteristics of used cooking oil biodiesel - A review. Renewable and Sustainable Energy Reviews, 14, 2863-2873.

Fazal, M. A.; Haseeb, A. S. M. A.; Masjuki, H. H. (2011). Biodiesel feasibility study: An evaluation of material compatibility; performance; emission and engine durability. Renewable and Sustainable Energy Reviews, 15, 1314-1324.

Garfield, E. (1999). Journal impact factor: a brief review. CMAJ. 161(8):979-980.

Grasman, S. E.; Sadashivam, S. (2012). Implementation policy considerations for achieving yearround operability of biodiesel programs. Biomass and Bioenergy, 39, 439-448.

Knothe, G. (2010). History of Vegetable Oil-Based Diesel Fuels. The Biodiesel Handbook (Second Edition), Pages 5-19, Academic Press and AOCS Press.

Kumar, S. et al. (2012). A comprehensive lifecycleassessment (LCA) of Jatropha biodiesel production in India . Bioresource Technology, 110, 723-729.

Kumar, S.; Chaube, A.; Jain, S. K. (2012). Critical review of jatropha biodiesel promotion policies in India. Energy Policy, 41, 775-781.

$\Theta$ Revista Gestão \& Tecnologia, Pedro Leopoldo, v. 19, n. 5, p. 189-206, out./dez. 2019204 
Lopes, D. C.; Neto, A. J. S.; Martins, P. A. R. (2011). Economic simulation of biodiesel production: SIMB-E tool. Energy Economics, 33, 1138-1145.

Lozada, I.; Islas, J.; Grande, G. (2010). Environmental and economic feasibility of palm oil biodiesel in the Mexican transportation sector. Renewable and Sustainable Energy Reviews, 14, 486-492.

Martins, C. A.; De Andrade Júnior, P.P. (2016).Production of biodiesel: Source strategies and efficiency in the Brazilian energy matrix. Energy Sources Part A-Recovery Utilization and Environmental Effects, 38, 277-285.

Meyer, D. D. (2011). Avaliação da biodegradabilidade de misturas de diesel e de biodiesel (B0, B20 e B100) em dois solos com diferentes granulometrias. 146 f. Dissertação (Mestre em Microbiologia Agrícola e do Ambiente) - UFRGS, Porto Alegre.

Ministério da Ciência e Tecnologia (2002). Programa brasileiro de biocombustíveis: rede brasileira de biodiesel - PROBIODIESEL. Recuperado em 28 Março, 2019 de http://www.anp.gov.br/biocombustiveis

Ministério das Minas e Energia. Balanço Energético Nacional 2010. (2006). Recuperado em 26 Março, 2019 de http://www.epe.gov.br/pt/publicacoes-dados-abertos/publicacoes/BalancoEnergetico-Nacional-2010

Ministério da Agricultura, Pecuária e Abastecimento. Programa Nacional de Produção e Uso do Biodiesel (2004). Recuperado em 20 de Março, 2019 de http://www.mda.gov.br/sitemda/secretaria/saf-biodiesel/o-que-\%C3\%A9-o-programanacional-de-produ\%C3\%A7\%C3\%A3o-e-uso-do-biodiesel-pnpb

Neto, J. A. A.; Almeida, C. M.; Pires, M. de M. (2004) Biodiesel: uma análise econômica e ambiental, 2004, João Pessoa-PB. IX Seminário Integrador - Ética, Desenvolvimento e Meio Ambiente. João Pessoa-PB: Prodema/UFPB.

Ong; H. C. et al. (2012). Life cycle cost and sensitivity analysis of palm biodiesel production. Fuel, 98, 131-139.

Papong, S. et al. (2010). Life cycle energy efficiency and potentials of biodiesel production from palm oil in Thailand. Energy Policy, 38, 226-233.

Peiró, L. T. et al. (2010). Extended exergy accounting applied to biodiesel production. Energy, 35, 2861-2869.

Peiró, L. T. et al. (2010). Life cycle assessment (LCA) and exergetic life cycle assessment (ELCA) of the production of biodiesel from used cooking oil (UCO). Energy, 35, 889-893.

Pienaar, J.; \& BRENT, A. C. (2012). A model for evaluating the economic feasibility of smallscale biodiesel production systems for on-farm fuel usage. Renewable Energy, 39, 483-489. 
Quintero, J. A. (2012). Social and techno-economical analysis of biodiesel production in Peru. Energy Policy, 43, 427-435.

Rathmann, R.; Szklo, A.; Schaeffer, R. (2012). Targets and results of the Brazilian Biodiesel Incentive Program - Has it reached the Promised Land? Applied Energy, 97, 91-100.

Shrake, S. O. (2010). A comparative analysis of performance and cost metrics associated with a diesel to biodiesel fleet transition. Energy Policy, 38, 7451-7456.

Szulczyk, K. R.; \& McCarl, B. A. (2010). Market penetration of biodiesel. Renewable and Sustainable Energy Reviews, 14, 2426-2433.

Wang, Z.; Calderon, M. M.; \& Lu, Y. (2011). Lifecycle assessment of the economic, environmental and energy performance of Jatrophacurcas L. biodiesel in China. Biomass and Bioenergy, 35, 2893-2902.

Xue, J.; Grift, T. E.; \& Hansen, A. C. (2011). Effect of biodiesel on engine performances and emissions. Renewable and Sustainable Energy Reviews, 15, 1098-1116.

Yanfen, L.; Zehao, H.; \& Xiaoqian, M. (2012). Energy analysis and environmental impacts of microalgal biodiesel in China. Energy Policy, 45, 142-151. 